\title{
Full-thickness Skin Biopsy of Nipple and Areola
}

National Cancer Institute

\section{Source}

National Cancer Institute. Full-thickness Skin Biopsy of Nipple and Areola. NCI Thesaurus.

Code C137850.

Removal of full-thickness skin tissue from the nipple and areola for microscopic examination. 